\begin{tabular}{|l|l|l|l|}
\hline Rudarsko-geološko-naftni zbornik & Vol. 17 & str. 27-30 & Zagreb, 2005. \\
\hline
\end{tabular}

\title{
IOR AND EOR - CHANCES FOR INCREASE OF OIL PRODUCTION AND RECOVERIES IN EXISTING, MATURE RESERVOIRS
}

\author{
JOSIP SEČEN
}

University of Zagreb, Faculty of Mining, Geology and Petroleum Engineering

Pierottijeva 6, 10000 Zagreb, Croatia

Key words: recovery, EOR methods, IOR processes

\section{Abstract}

After the application of conventional oil extraction techniques, about $2 / 3$ of discovered reserves still remain to be produced. In view of high probability for oil presence and oil price increases, investments in research of possibilities for higher recoveries and higher production with application of appropriate IOR and EOR methods are justified, naturally under economic conditions.

\section{Introduction}

Let us assume the position of owner or at least oil company director, whose main task is renewal of reserves, and whose business success is measured by reserve replacement ratio.
Ključne riječi: iscrpak, EOR metode, IOR postupci

\section{Sažetak}

Nakon primjene konvencionalnih metoda iskorištavanja naftnih ležišta, u njima ostaju nepridobive $2 / 3$ od otkrivenih količina. U okolnostima velike vjerojatnosti njihova postojanja i visoke cijene nafte, opravdana su ulaganja u istraživanja mogućnosti povećanja njihova iscrpka i proizvodnje u svim fazama iskorištavanja ležišta primjenom IOR postupaka (poboljšanih metoda iskorištavanja) i EOR metoda (metoda povećanja iscrpka), naravno pod profitabilnim uvjetima.

New recoverable reserves of oil and gas can be obtained in the following manner ${ }^{(3)}$ :

- Discovery of new reservoirs as a consequence of continuous pursuit of basic activity - exploration of domestic and foreign exploration areas;

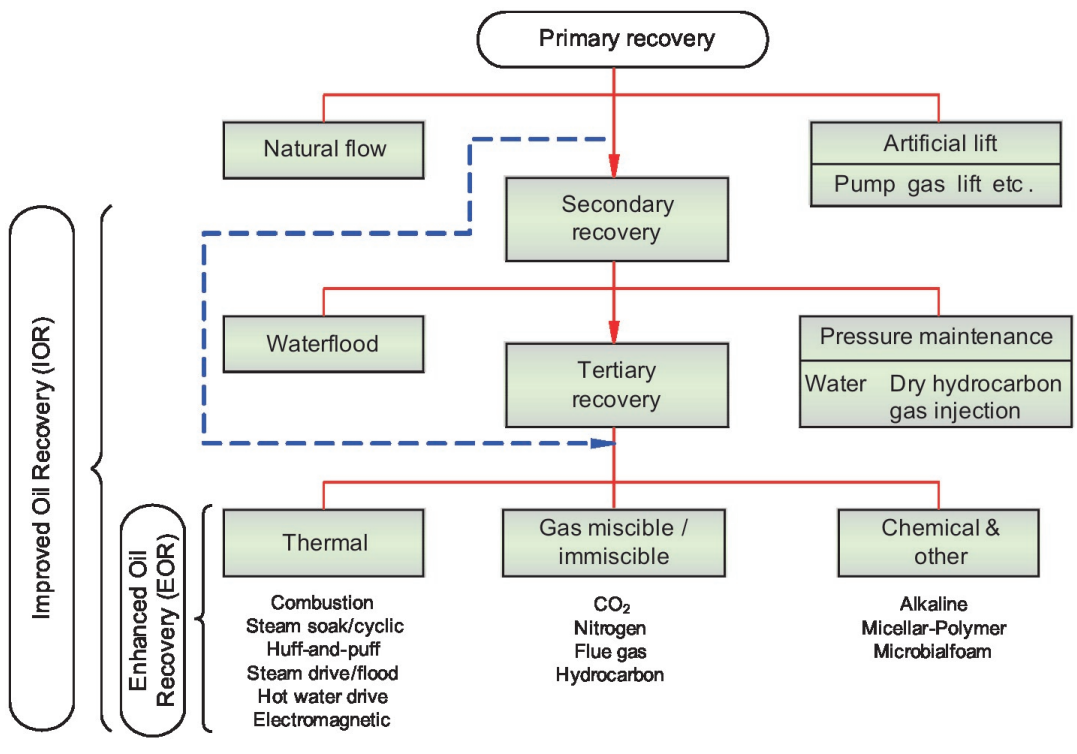

Figure 1 Proposed definitions of the EOR and IOR terms ${ }^{(8)}$

Slika 1. Predložena definicija EOR metoda i IOR postupaka ${ }^{(8)}$ 
- Improvement of reservoir models by application of new geophysical methods, state-of-the-art interpretation techniques and reinterpretation of all available data in combination with data obtained during reservoir exploitation (produced quantities of uid and change in reservoir pressure);

- Application of EOR methods in reservoirs with inefficient displacement drives:

- in the secondary stage of oil displacement by physical activity - injection of water or gas into the reservoir;

- in the tertiary stage by freeing oil trapped in pore space after secondary stage by thermal or chemical activity - through application of EOR processes;

- Introduction of new technologies on existing fields: infill drilling, recompletions, fracturing, drilling of horizontal wells and sidetracking from existing holes to activate less permeable parts of the reservoir and catch the by-passed oil by IOR processes or reservoir management.

1. EOR methods, also known as tertiary recovery methods, mobilize oil trapped by capillary and viscosity forces during reservoir water ooding in the secondary stage. Oil is freed by chemical and thermal activity, by injecting solvents and chemicals and heating of the reservoir.

2. IOR processes are applied mainly in the secondary and tertiary reservoir depletion stage to increase reservoir sweep efficiency coefficients by displacing uids - looking for trapped oil by denser well spacing pattern, drilling of horizontal wells and sidetracking from existing holes, fracturing and use of polymers to improve uid mobility ratio.

\section{Exploration of domestic and foreign areas}

Common problem of Central European oil companies is high degree of exploration of domestic exploration areas, without great probability for discovery of larger quantities of hydrocarbons. The situation in Croatia is a good example ${ }^{(1)}$.

The territory of Croatia is divided in three exploration areas: the Pannonian basin, the Dinarides and the Adriatic offshore. A total of 332,6 million $\mathrm{m}^{3}$ of oil and condensate and 129,8 billion $\mathrm{m}^{3}$ of natural gas were discovered so far from 34 oil fields and 20 gas and gas-condensate fields. All oil was discovered in the Pannonian basin, and most of gas comes from the Pannonian basin and partly from the Adriatic offshore.

Despite great efforts, there were no major discoveries in the Pannonian basin in the last 20 years. We have to answer two important questions:

- Is the Pannonian basin sufficiently explored, and

- Is there a probability for discovery of new, larger quantities of hydrocarbons?

According to evaluations made within the framework of hydrocarbon potential investigation studies for the Croatian part of the Pannonian basin, two to four times more hydrocarbons were generated than they are discovered so far, which means that between 900 and 1800 million $\mathrm{m}^{3}$ of undiscovered quantities of oil equivalent could still be present in the subsurface. However, in spite of numerous seismic surveys and drilling of 850 exploratory and 2780 production wells, these assumptions have not been confirmed.

Evaluation of possible discoveries of hydrocarbons were made applying the Arps-Roberts method. based on areas and reserves of hydrocarbons in already discovered fields. The data from 52 oil, gas and gas-condensate fields were processed.

Results of evaluations are shown in Table 1. According to analysis results, exploration targets were small and probability for discovery was low, but they could still be attractive due to available infrastructure for treatment and transportation of hydrocarbons.

Table 1 Calculation of ultimate number of fields in each size class

Tablica 1. Izračunati konačni broj polja po klasama površina i zaliha ugljikovodika

\begin{tabular}{|c|c|c|c|c|c|c|c|c|}
\hline Class & $\begin{array}{l}\text { Number } \\
\text { of Fields }\end{array}$ & $\begin{array}{l}\text { Number } \\
\text { of Fields } \\
\text { Smoothed }\end{array}$ & $\begin{array}{l}\text { Tolal } \\
\text { Area of } \\
\text { Fields }\end{array}$ & $\begin{array}{c}\text { Average } \\
\text { Production } \\
\text { Area }\end{array}$ & $\begin{array}{l}\text { Original } \\
\text { Oil in } \\
\text { Place }\end{array}$ & $\begin{array}{l}\text { Estimated } \\
\text { Number of } \\
\text { Fields }\end{array}$ & $\begin{array}{c}\text { Total } \\
\text { Productive } \\
\text { Area }\end{array}$ & $\begin{array}{l}\text { Original } \\
\text { Oil in } \\
\text { Place }\end{array}$ \\
\hline & & & $\left(\mathrm{km}^{2}\right)$ & $\left(\mathrm{km}^{2}\right)$ & $\left(1000 \mathrm{~m}^{3}\right)$ & & $\left(\mathrm{km}^{2}\right)$ & $\left(1000 \mathrm{~m}^{3}\right)$ \\
\hline & $K_{i}$ & $K_{i}$ & $A_{i}$ & $A_{I}$ & $\overline{R_{u i}}$ & $K_{\alpha}$ & $K_{\alpha}{ }^{*} A_{i}$ & $\boldsymbol{K}_{p i}{ }^{*} R_{w}$ \\
\hline 1 & 4 & 2.78 & 1.19 & 0.43 & 1129 & 56.6 & 24.2 & 63883 \\
\hline 2 & 7 & 6.61 & 6.90 & 1.04 & 1128 & 569 & 59.5 & 64227 \\
\hline 3 & 10 & 10.89 & 23.92 & 2.20 & 2406 & 47.7 & 104.8 & 114781 \\
\hline 4 & 13 & 12.48 & 55.27 & 4.43 & 4091 & 30.7 & 135.8 & 125440 \\
\hline 5 & 11 & 9.94 & 97.56 & 9.82 & 14865 & 14.5 & 142.2 & 215314 \\
\hline 6 & 5 & 5.50 & 82.71 & 15.04 & 25677 & 6.6 & 99.6 & 169976 \\
\hline 7 & 2 & 2.11 & 90.11 & 42.63 & 30214 & 2.1 & 90.7 & 64294 \\
\hline Total & 52 & 50.31 & 357.66 & 7.11 & 440612 & 215.1 & 656.7 & 817914 \\
\hline
\end{tabular}


These results point out the only possible solution - exploration of insufficiently explored domestic exploration areas, in this case primarily the Dinarides, and foreign exploration areas. Will it be independently or jointly with other companies depends on the financial strength and company policy.

\section{EOR methods}

High depletion of oil reservoirs discovered several decades ago is attributable to high exploration of the larger part of the European continent. Conventional enhanced oil recovery methods, such as water ooding and gas injection, were applied successfully in this area. We know about experiments with thermal processes in Romania and Hungary and displacement of oil with $\mathrm{CO}_{2}$ was attempted in Austria, Hungary, etc.

According to natural depletion drives, recovery for all discovered oil reserves in Croatia was only about 25 $\%^{(2)}$. Recoveries were the smallest in the reservoirs with the largest reserves. Afterwards, following the world practice and effectiveness of natural water drive, reservoir pressure maintenance method by injection of water into 8 reservoirs/fields and gas injection into one field has been applied since 1972. Water ooding is applied on $58 \%$ of all discovered reserves. By this processes recoverable oil reserves were increased by approx. 30 million $\mathrm{m}^{3}$, and recovery from earlier mentioned 25,00 to $34,45 \%$.

By the end of 2002 total production of oil at recovery of $32,5 \%$ reached 102,0 million $\mathrm{m}^{3}$ and remaining recoverable oil quantities are estimated at about 7,0 million $\mathrm{m}^{3}$. The status of reserves, in percentages, is presented in Table 2.

Table 2 Oil recovery rates and oil reservoir depletion methods, $\%$

Tablica 2. Iscrpci nafte u raznim fazama iskorištavanja ležišta

\begin{tabular}{|c|r|}
\hline Recoverable & \multicolumn{2}{|c|}{34,45} \\
- recovered & 32,50 \\
-primary recovery & 50,91 \\
-secondary recovery & 49,09 \\
-tertiary recovery & 0,00 \\
- remainder & 1,90 \\
Unrecoverable & 65,55 \\
\hline
\end{tabular}

In spite of such good results achieved by water ooding, oil production has been constantly decreasing since 1981 . The question is how to stop such production decrease. The solution lies in emerging of an idea how to recover a part of remaining 205,2 million $\mathrm{m}^{3}$ of currently unrecoverable oil reserves.
The idea how to increase oil recovery from water ooded reservoirs in tertiary stage of production has been developing for a long time. The solution was found in $\mathrm{CO}_{2}$ injection as the most efficient method, since in addition to its positive characteristics and proved efficiency, $\mathrm{CO}_{2}$ is available in high quantities, at present discharged into the atmosphere. Possible application is expected in the near future, primarily on Ivanić and Žutica fields. Numerous laboratory analyses, studies and numeric simulations were carried out and they indicate possibility for recovery increase by 12 to $14 \%$ under miscibility or near miscibility conditions.

Economic valuation for one of the projects ${ }^{(6)}$ was done for different variants:

- Variant A - extension of existing water ooding system

- Variant B - oil displacement with $\mathrm{CO}_{2}$.

with oil price at $20 \$ / \mathrm{bbl}\left(125,8 \$ / \mathrm{m}^{3}\right)$ and gas price at $0,12 \$ / \mathrm{m}^{3}$ and discounted rate of $10 \%$. The obtained results are as follows:

- Positive project duration:

variant $\mathrm{A}-10$ years

variant $\mathrm{B}-23$ years or more

- Expected future total production:

\begin{tabular}{c|c|c} 
Variant & $\begin{array}{c}\text { Oil } \\
\text { tons }\end{array}$ & $\begin{array}{c}\text { Gas } \\
10^{3} \mathrm{~m}^{3}\end{array}$ \\
\hline $\mathrm{A}$ & 1538295 & 445018 \\
\hline $\mathrm{B}$ & 5462283 & 1302620 \\
\hline Difference & 3923988 & 866602
\end{tabular}

- Net present value: variant A - $32264000 \$$ variant B - 50144000 \$

- Payout period: variant $A$ - 2 years variant $B-12$ years

- value of investments and production costs per unit of product, $\$ / \mathrm{BOE}$

\begin{tabular}{c|c|c|c} 
Variant & Capex & Opex & Total \\
\hline A & 1,12 & 15,01 & 16,13 \\
\hline B & 2,19 & 9,81 & 12,00
\end{tabular}

After application in these fields, the method could be extended to other fields in the same region. 


\section{IOR processes}

Good results should also be expected from application of IOR processes, regardless of the manner of realization. The study on possibilities to search for bypassed oil in highly water ooded part of the reservoir on Šandrovac ${ }^{(7)}$ field was also prepared.

Analysis of sedimentation conditions, effective thicknesses, injected water ood front shifting as well as achieved recoveries from well drainage areas, helped locate the areas for 10 side-tracked holes and one horizontal well. They would double the quantity of oil in comparison with current production, with recovery rate increase by $5,8 \%$. Planned investments amount to approx. $500000 \$$ per well. With oil price at $16 \$ / \mathrm{bbl}$ and discounted rate of $10 \%$, net present value of 15,1 million $\$$ was obtained, while payout time was one year and 10 months.

All such projects are burdened with high water cut in produced uid. Hopefully, the problem will be solved in the near future. At a time when produced quantities of oil are accompanied by twice as large quantities of water, the problem is of global proportions and its solution would considerably reduce production costs.

\section{Conclusion}

These considerations point out the need for exploration in new promising areas and applying of IOR processes and EOR methods on existing fields.
Produced indigenous oil is more valuable for domestic economy than imported oil and oil companies, scientists and experts from this sphere of activity face a permanent task how to maintain production levels and increase recovery from existing old fields in a profitable manner.

\section{References}

Sečen, J., Prnić, Ž., Valjak, M., Probable Discoveries of Hydrocarbon Reservoirs in Croatian Part of Pannonian Basin, Proceedings of 2nd International Symposium on Petroleum Geology, Zagreb, April 22. - 24., 1999, 73 - 78.

Sečen,J., Perić,M., Bauk,A,. Possibilities for Recovery Oil by Injection of $\mathrm{CO}_{2}$ in the Tertiary Recovery Stage, Proceedings of International Oil and Gas Conference, Zadar, Croatia, 2. - 5. October, 2001, $432-442$.

Sečen,J., Bauk,A., Revitalization of Old Oil Fields, Proceedings of International Oil and Gas Conference, Zadar, Croatia, 2. - 5. October, 2001, $443-450$.

What's Ahead in 2001, World Oil, December 2000, 34 - 35.

Projekt CO2 - Naftna polja Ivanić i Žutica, INA-Industrija nafte d.d. Zagreb, Naftaplin, Zagreb, Studeni 1997.

DOE Fossil Energy-Oil and Gas: Reservoir Life Extension, http: //www.fe.doe.gov

Stručna dokumentacija INA-Industrija nafte d.d. Zagreb, Naftaplin, Šubićeva 29.

Moritis,G., EOR Weathers Low Oil Prices, OGJ Special, March 20, 2000 